\title{
Pastoral Livestock Marketing: A Case Study of Marsabit County, Kenya
}

\author{
Tura Isako $^{1^{*}} \quad$ Victoria Kimindu ${ }^{1}$ Set Amboga ${ }^{2}$ Guyo Tuke ${ }^{3}$ \\ 1.Beef Research Institute, Lanet Center, P.O. Box 3840-20100 Nakuru, Kenya \\ 2.Food Crops Research Institute, Embu Centre, P.O. Box 27-60100 Embu, Kenya \\ 3.Livestock and NRM Program at Food for the Hungry Kenya, Marsabit County, Kenya
}

\begin{abstract}
The study aimed to evaluate the current status of livestock marketing in Marsabit County. A survey was conducted in six markets using pre-tested semi-structured questionnaires to gather data. The Market committees interviewed were purposefully selected while traders sampled were identified using simple systematic random sampling. The data was analyzed using SPSS Version 25. Descriptive statistics, cross tabulation, and means comparison was analyzed based on markets location. This study revealed that pastoral markets suffer from several inefficiencies such as low purchasing power, recurring droughts that made livestock a risky business, low levels of education and limited business skills among the traders, and lack of banking and credit facilities. The role of the youth is pivotal in the steering the future of livestock production and trade in the ASAL. Thus the study recommends capacity building of traders to enhance their business skills, linking of traders with banking, loaning institutions, modern abattoir for export markets and innovative ways of mitigating drought related risks.
\end{abstract}

Keywords: pastoralists, livestock marketing, traders, market inefficiencies.

DOI: $10.7176 / \mathrm{JNSR} / 9-6-07$

Publication date:March $31^{\text {st }} 2019$

\section{Introduction}

The arid and semi-arid lands (ASAL) of Kenya make up more than $80 \%$ of Kenya's landmass, support $70 \%$ of the livestock population in the country and about $30 \%$ of the total human population (Barret et al., 2003). $90 \%$ of the wild game that supports much of the tourism sector in Kenya sits in the ASAL and much of Kenya's potential and exploited commercial mineral wealth is in the ASAL. In the midst of the high development potential, this region suffers the highest incidences of poverty in Kenya, where it is estimated that $60 \%$ of the population subsists less than one US dollar a day (GoK, 2005). Due to its fragile ecosystems, vastness of the area, unreliable rainfalls, poor infrastructures and unfavorable development policies, these areas pose a major development challenges for the Government and other development agents. In Kenya, pastoralists constitute about $25 \%$ of the population and are socially and economically dependent on livestock (Kibue, 2008). Pastoralists traditionally keep livestock for provision of food and as a precious form of wealth and heritage that they exceedingly hold on to. However, modernization has made pastoralists to change diets, settle to access basic amenities like schools and hospitals and even frequently indulge in livestock trade as a key economic activity to cope with cash economy. This accelerated sedentarization, increased aridity and climate variability has resulted to high livestock mortality that if the livestock had been earlier utilized for trade would have averted the high poverty levels impoverishing the pastoralists. Despite these major losses resulting from droughts and occasional floods, pastoralists still keep large herds of livestock with limited off-takes and have few drought mitigation measures that its related mortality always exceeds net sales. According to Mcpeak and Barret 2001, household sales rate among the pastoralists is $12 \%$ while mortality is $53 \%$ in drought seasons.

As a way to enhance livestock marketing chains, several development agents are supporting livestock marketing in pastoral areas. However, there is information gap regarding the impact of the interventions and market performance thus necessitated this study.

\section{Materials and Methods}

\subsection{Characteristics of the study areas}

Marsabit County lies between latitude $01^{\circ} 15^{\prime}$ north and $04^{\circ} 27^{\prime}$ north, and longitude $36^{\circ} 3^{\prime}$ ' east and $38^{\circ} 59^{\prime}$ east in the former Eastern Province (Figure 1). It is located $550 \mathrm{~km}$ north of the capital Nairobi and is the largest county in Kenya covering 70, $961.3 \mathrm{~km}^{2}$. Marsabit borders three counties; Wajir to the east, Turkana to the west and Isiolo to the south. It also borders Ethiopia to the north (GoK, 1997).

With a population of more than 291,000 people, the poverty rate has been established to be $42.2 \%$ while the population with primary and secondary education at $70.4 \%$ and $8.9 \%$ respectively (GoK/UNDP, 2013). Only $7 \%$ of individuals are in wage-earning category in the county and about $10 \%$ of people in urban and $18 \%$ of people in rural are in self-employment (Marsabit County Government, 2018). 
Figure 1. Map of markets under study in Marsabit County

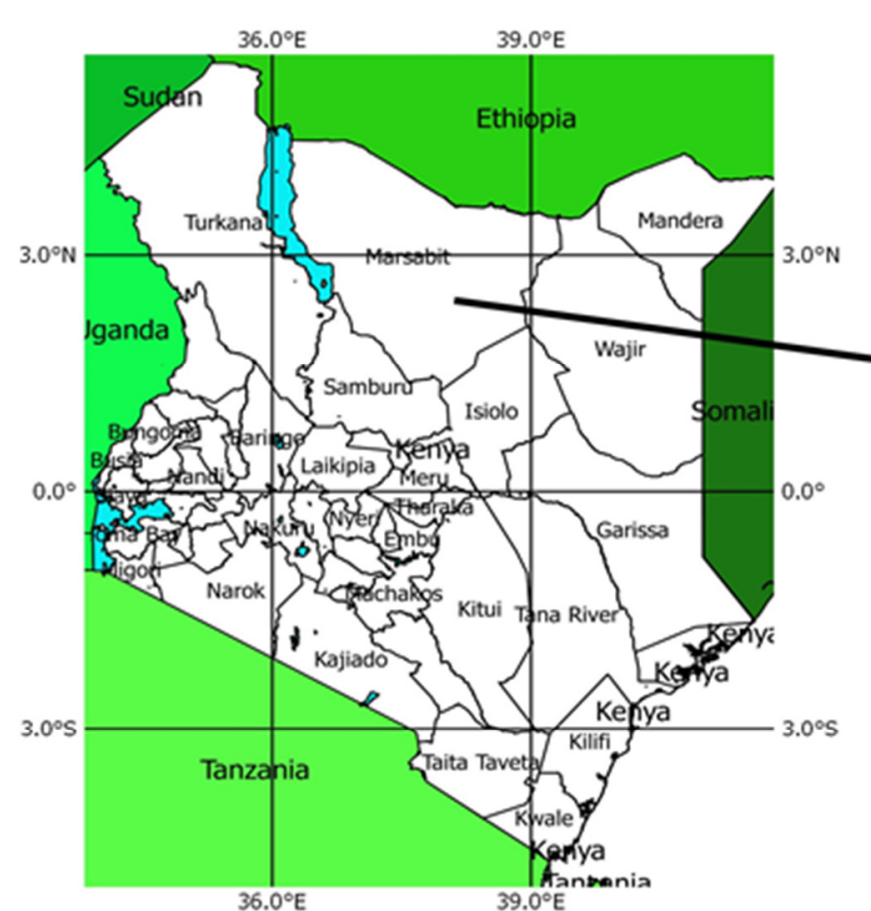

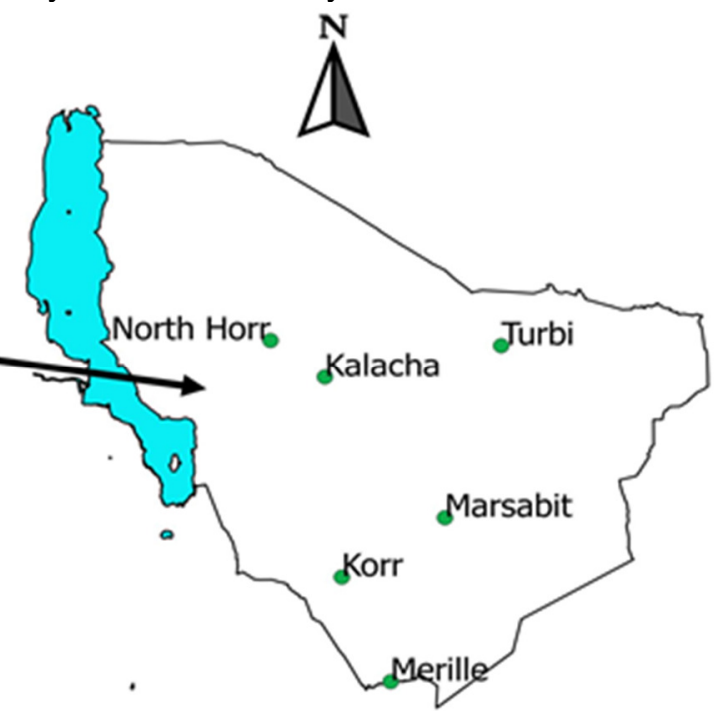

Legend

- Marsabit Markets

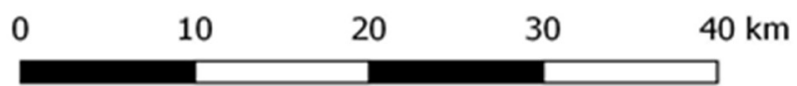

The county is categorized into 4 Agro-Ecological Zones namely: Zone II: Sub-humid/forest zones which covers $1 \%$ of the county serves as a water catchment area; Zone IV: Semi-arid/woodland zones that cover $10 \%$ and has enabled sedentarilized agro-pastoral production; Zone V: Arid/bushland zones cover 13\% having shallow and stony clay loams soils and Zone VI: Very arid/scrublands covering $69 \%$ of the county having only dwarfshrub vegetation (Marsabit County Government, 2018).

Livestock keeping is the main economic activity in Marsabit and the main livestock kept include approximately 420,000 cattle, 2,029,490 goats, 1,851,452 sheep, 217,360 camels, 81,900 donkeys and 45,860 chickens (Marsabit County Government, 2018). The main livestock products are milk, beef, mutton and camel meat.

The study was undertaken in six markets in Marsabit County: Turbi, North-Horr, Kalacha, Marsabit, Korr and Merille as illustrated in Figure 1.

\subsection{Data collection method and sampling procedure}

Survey targeting livestock traders buying in primary markets and selling to secondary and terminal markets was conducted using pre-tested semi-structured questionnaires. The sampling frame for the study was the total number of livestock traders in a given market that were identified by the market committees. The unit of analysis for the study was the traders identified for the survey. The study used simple systematic random sampling technique to sample the $n$th trader to be interviewed.

In Marsabit central markets the committee listed about 48 active traders, North-Horr 46, Kalacha, 37, Turbi 39, Korr 36 and Merille 56. In each market 8 traders were sampled using simple systematic random sampling and two market committees who were also traders were purposefully sampled from the same sampling frame. All traders in each market were first listed to get the sampling interval, the sampling frame was divided by the sample size for instance in Marsabit, central market 48 (sampling frame) /10 (sample size). In this case, the sampling interval was 4.8 and the starting number was between 1 and 5, and by way of randomization, number 2 became the starting number generated from the table of random numbers. From number 2, every $5^{\text {th }}$ trader was selected for interviewing from the list of traders (Moser and Kalton 1985; Barnett 1991). Structured questionnaires were divided into two sections: section one captured bio-data regarding the traders and section two addressed market data. Data was entered and analyzed using statistical package for socio-scientists (SPSS) version 25 computer package: Descriptive, cross tabs, means comparison was analyzed based on markets location. 


\section{Results and Discussions}

\subsection{Traders level of education and occupation}

In each market 10 traders were interviewed and between $33-90 \%$ of traders across all the markets had not gone to any formal school. The illiteracy levels were very high among Marsabit central market (90\%) and Merille (60\%) traders and low among the Korr (33\%) and North-Horr (33.3\%) traders (Table 1).

Table 1. Traders' general information

Level of education: $N=$ none, $A E=$ adult education, $L P=$ lower primary, $U P=$ upper primary $S=$ secondary. Occupation: $L T=L i v e s t o c k$ trader LTHW=Livestock trader and housewife, $L T H=$ Livestock trader and herder SELT $=$ salaried employment and livestock trader

\begin{tabular}{|c|c|c|c|c|c|c|c|c|c|}
\hline \multirow{2}{*}{$\begin{array}{l}\text { Market } \\
\text { location }\end{array}$} & \multicolumn{5}{|c|}{ Level of education (\%) } & \multicolumn{4}{|c|}{ Occupation (\%) } \\
\hline & $\mathrm{N}$ & $\mathrm{AE}$ & LP & UP & $\mathrm{S}$ & LT & $\mathrm{L} \mathrm{T} \mathrm{H} \mathrm{W}$ & $\mathrm{L} \mathrm{TH}$ & SELT \\
\hline N. Horr & 33.3 & 0 & 16.7 & 33.3 & 16.7 & 100 & 0 & 0 & 0 \\
\hline Kalacha & 55.6 & 0 & 11.1 & 22.2 & 11.7 & 77.8 & 11.1 & 11.1 & 0 \\
\hline Turbi & 50 & 33.3 & 0 & 0 & 16.7 & 100 & 0 & 0 & 0 \\
\hline Marsabit & 90 & 0 & 10 & 0 & 0 & 90 & 0 & 10 & 0 \\
\hline Korr & 33 & 33 & 0 & 33 & 0 & 75 & 0 & 0 & 25 \\
\hline Merille & 60 & 0 & 20 & 20 & 0 & 100 & 0 & 0 & 0 \\
\hline
\end{tabular}

All the traders from North-Horr, Turbi and Merille markets were full time (100\%) livestock traders. In Korr market, $75 \%$ of the respondents were full time livestock traders while $25 \%$ were also engaged in salaried employment in addition to livestock trade. In Kalacha $77.8 \%$ reported to be fully doing livestock trade, $11.1 \%$ also have responsibility of being house wives and $11.1 \%$ herd and also do livestock trade. In Marsabit central market, $90 \%$ of traders reported to be fulltime traders while $10 \%$ claim to combine trading and livestock keeping.

The low education levels among traders lead to difficulty in transacting and monitoring bank accounts. NorthHorr and Korr traders have more literate members because of strong presences of missionaries in those areas that started schools immediately after the independence and thus those who had gone to school and did not attain formal employment saw livestock trade as an opportunity. This had assisted traders organized into trader groups and could attempt to control livestock supply to the terminal markets. High illiteracy levels among Marsabit central traders were attributed to aged male traders and large number of women respondents.

\subsection{Period in business and mode of transaction}

Majority of traders were less than 10 years old in livestock trade with $90 \%$ of traders in Merille markets having started trade between 1-5 years (Table 2). The mode of purchasing in all the six markets is strictly by cash (100\%). Owing to few years in business, traders have limited business skills, evidenced by traders preferring cash transactions coupled with the lack of banking facilities.

Table 2. Period in small ruminant business

\begin{tabular}{|c|c|c|c|c|c|c|}
\hline \multirow{2}{*}{$\begin{array}{c}\text { Period in business } \\
\text { (years) }\end{array}$} & \multicolumn{6}{|c|}{ Market locations } \\
\cline { 2 - 6 } & North-Horr & Kalacha & Turbi & Marsabit & Korr & Merille \\
\hline$<1$ & 1 & 0 & 0 & 1 & 2 & 1 \\
\hline $1-5$ & 2 & 3 & 4 & 5 & 4 & 8 \\
\hline $6-10$ & 2 & 3 & 4 & 3 & 4 & 1 \\
\hline $11-15$ & 3 & 3 & 2 & 0 & 0 & 0 \\
\hline $16-20$ & 0 & 1 & 0 & 1 & 0 & 0 \\
\hline$>20$ & 2 & 0 & 0 & 0 & 0 & 0 \\
\hline
\end{tabular}

3.3 Market organization, accessibility and reliability

All the markets in the study area are managed by livestock market management committees (LMMC) that regulate market prices, the number of animals going to secondary and terminal markets and scheduled and trucks ferrying animals to markets. North-Horr market fully (100\%) controls the supply of livestock to terminal and secondary markets. The fact that some traders in North-Horr market have secondary level of education revealed their understanding on the benefits of regulated livestock supply to markets to avoid surplus and price fluctuations. Turbi market had no control of livestock sold to terminal markets.

Several measures have been put in place by different markets in controlling supply of livestock to terminal markets. Truck control method is popular in Kalacha (67\%), Korr (67\%) and Merille (50\%) markets while the regulating livestock supply was mostly practiced in North Horr (67\%), Merille (50\%) and Korr (33\%). Only NorthHorr reported having a committee that control livestock market supply to secondary and terminal markets.

All the markets were reported to have set market days apart from Marsabit central market that was operating on all days of the week. North-Horr, Kalacha and Turbi, Korr and Merille markets are most accessible to livestock 
keepers because they are located in core areas of rearing livestock while Marsabit central market was mainly accessed by traders and about $50 \%$ of the livestock keepers.

Apart from Marsabit central market that is reliable and acted as secondary market to other five markets, the others are highly seasonal since they are located in main pastoral settlement and around such areas pastures are limited and thus livestock supplies to these markets are low mostly during dry seasons. Marsabit market is a reliable market for several reasons such as availability of many buyers, access to banking facilities, road and transport but it is not easily accessible to livestock keepers who have to pay for truck costs to access the market.

\subsection{Sources of initial capital and initial problems to business}

There are two ways that traders across markets acquired their initial capital for the business: own sources and borrowed from informal trader groups. Traders in Turbi, Marsabit central, Korr and Merille markets reported to use own sources. Most of them sale their own animals while others borrow animals or money from friends and relatives to initiate their business. Traders in North-Horr (25\%) and Kalacha (33.3\%) acquired their initial capital from informal trader groups which give small loans to their members to be paid back with a small interest (1\%) on monthly basis. Other development agents that were mentioned to give loans or grants are the Ministry of livestock under 'njaa marufuku' project, Pastoralists integrated support project (PISP) and Livestock Marketing Council among others. High capital requirement in starting the business was cited by all market players in Merille $(100 \%)$, North- Horr (50\%), Turbi (50\%), Marsabit (50\%), Korr (50\%) and Kalacha (40\%) as an initial problem to starting livestock trade. The lack of loaning facilities was reported as second major problem in North -Horr (25\%), Marsabit (20\%), Korr (25\%) and Kalacha (20\%) while poor and fluctuating market prices were mentioned as a third major initial problem in North- Horr (25\%), Kalacha (40\%), Marsabit (25\%) and Korr (25\%). High cost of transporting livestock to secondary and terminal markets was cited in Turbi (50\%) and Marsabit (10\%).

\subsection{Working capital}

$50-70 \%$ of traders in Turbi, Marsabit central, Korr and Merille operated with capital less than Ksh. 10,000 while $90 \%$ Kalacha and $60 \%$ of North-Horr traders' operational capitals falls between Ksh. 10,000-40,000. 20\% of traders in North-Horr, Kalacha (10\%), Marsabit (10\%) and Korr (20\%) operate with capital between Ksh. 100,000$200,000.20 \%$ of North-Horr traders operate with capital of over Ksh. 200,000 and these are mainly traders selling to terminal markets as summarized in Table 3.

Table 3. Working capital among the traders

\begin{tabular}{|c|c|c|c|c|c|c|}
\hline \multirow{2}{*}{ Working capital } & \multicolumn{7}{|c|}{ Market locations } \\
\cline { 2 - 7 } & $\begin{array}{c}\text { North-Horr } \\
(\mathrm{n}=10)\end{array}$ & $\begin{array}{c}\text { Kalacha } \\
(\mathrm{n}=10)\end{array}$ & $\begin{array}{c}\text { Turbi } \\
(\mathrm{n}=10)\end{array}$ & $\begin{array}{c}\text { Marsabit } \\
(\mathrm{n}=10)\end{array}$ & $\begin{array}{c}\text { Korr } \\
(\mathrm{n}=10)\end{array}$ & $\begin{array}{c}\text { Merille } \\
(\mathrm{n}=10)\end{array}$ \\
\hline$<10,000$ & 1 & 3 & 5 & 7 & 6 & 7 \\
\hline $10-20,000$ & 3 & 3 & 2 & 1 & 1 & 3 \\
\hline $20-40,000$ & 2 & 3 & 3 & 1 & 1 & 0 \\
\hline $100-200,000$ & 2 & 1 & 0 & 1 & 2 & 0 \\
\hline$>200,000$ & 2 & 0 & 0 & 0 & 0 & 0 \\
\hline
\end{tabular}

\subsection{Types of buyers in the markets}

There are three types of buyers reported in the markets studied: Individual buyers, community groups and external traders. In North-Horr, Kalacha, Turbi and Korr buying and selling of livestock is done by individual traders. In Marsabit, $70 \%$ of the traders buy as individuals while $20 \%$ are community groups and $10 \%$ are external traders. In Merille markets $40 \%$ of traders were individuals, $40 \%$ of traders belong to community groups and $20 \%$ were external traders mainly from Marsabit and Isiolo.

\subsection{Estimated cost incurred per trip to Nairobi}

Road networks and infrastructure in Marsabit County covers a very small fraction of the region and if present, are largely dry weather roads that are mostly impassable during rainy seasons. Out of the current road network of approximately $5,000 \mathrm{~km}, 312 \mathrm{~km}$ is tarmacked, $580 \mathrm{~km}$ is gravel surface and $4,108 \mathrm{~km}$ is earth surface (GoK/UNDP, 2013).

In our study, traders reported numerous costs during bulking animals to fill up a truck destined to terminal markets. Loading of livestock to vehicles is the most expensive livestock cost incurred in the trade especially in Korr and Merille markets where a trader can spend to a tune of ksh.50,800 and Ksh. 42,800 respectively. Other costly items in trading are payment of broker fees, council tax, caretaker fees and animal health certification. Generally, livestock trading is more costly in Korr, Turbi and Merille markets (Table 4). 
Table 4. Cost estimate incurred per trip to the capital city, Nairobi

\begin{tabular}{|c|c|c|c|c|c|c|c|c|c|c|}
\hline \multicolumn{11}{|c|}{$\begin{array}{l}B=\text { Boma, } C T=\text { care taker, } B L C=\text { Buying labour cost }, C C=\text { council cess, } B r=\text { brooker, } \\
V T=\text { Veterinary fees, } T F=\text { Truck Fees } P=\text { permit } G=\text { guard }\end{array}$} \\
\hline \multirow[t]{2}{*}{ Market } & \multicolumn{10}{|c|}{ Cost (KES) on hiring } \\
\hline & $\mathrm{B}$ & $\mathrm{CT}$ & BLC & $\mathrm{Br}$ & $\mathrm{CC}$ & VF & $\mathrm{P}$ & G & $\mathrm{TF}$ & Total cost \\
\hline North Horr & 325 & 3450 & - & 2470 & 4860 & 550 & 700 & - & 35600 & \\
\hline Kalacha & 110 & 530 & 3500 & 810 & 3040 & 1980 & 280 & - & 36700 & \\
\hline Turbi & - & 4000 & - & 1630 & 3680 & 700 & - & 3000 & 40000 & \\
\hline Marsabit & 2060 & 4640 & 5000 & 2000 & 2480 & - & 1120 & 2400 & 25100 & 44 \\
\hline Korr & 650 & 2200 & - & 6060 & 7000 & 900 & 1300 & - & 50850 & 68960 \\
\hline Merille & 2000 & 1750 & 1750 & 3950 & 4210 & - & 500 & - & 42800 & 56960 \\
\hline Totals & 5145 & 16570 & 10250 & 16920 & 25270 & 4130 & 3900 & 5400 & 231050 & 318635 \\
\hline
\end{tabular}

\subsection{Challenges facing the markets}

There are several challenges in these markets and some are specific to individual markets. The major challenges facing all markets are as follows and have been summarized in Table 5.

Table 5. Challenges facing the market

\begin{tabular}{|c|c|c|c|c|c|c|}
\hline \multirow[t]{2}{*}{ Challenges } & \multicolumn{6}{|c|}{ Markets \% } \\
\hline & $\begin{array}{l}\text { North- } \\
\text { Horr } \\
\text { n=10 }\end{array}$ & $\begin{array}{l}\text { Kalacha } \\
n=10\end{array}$ & $\begin{array}{l}\text { Turbi } \\
n=10\end{array}$ & $\begin{array}{l}\text { Marsabit } \\
n=10\end{array}$ & $\begin{array}{l}\text { Korr } \\
n=10\end{array}$ & $\begin{array}{l}\text { Merille } \\
n=10\end{array}$ \\
\hline Limited capital & 50 & 50 & 20 & 40 & 40 & 40 \\
\hline Livestock diseases & 0 & 0 & 0 & 0 & 10 & 10 \\
\hline droughts & 20 & 40 & 40 & 20 & 20 & 20 \\
\hline Cess & 0 & 0 & 0 & 10 & 10 & 0 \\
\hline $\begin{array}{l}\text { Fluctuating market } \\
\text { prices }\end{array}$ & 20 & 10 & 10 & 20 & 10 & 10 \\
\hline quarantine & 0 & 0 & 0 & 0 & 10 & 10 \\
\hline Insecurity & 10 & 0 & 10 & 0 & 0 & 10 \\
\hline Lack of water & 0 & 0 & 20 & 10 & 0 & 0 \\
\hline
\end{tabular}

i. Limited capital has been cited as a major market development challenge in North-Horr (50\%), Kalacha (50\%), Turbi (20\%), Marsabit (40\%), Korr (40\%) and Merille (40\%), contributed partly to inadequate financial services in these pastoral areas. Loan provision services are few and limited to registered groups. It was also reported that some of the traders were not keen to access these services seeing that livestock production returns are much better than bank loans.

ii. Drought in Kenya has been occurring with greater frequency in the second half of the 20th century compared to the first, with severe droughts reported in 1960-61, 1968-69, 1974-76, 1979-81, 1991-93, 1996, 2000, 2004-05, 2008-11, 2017-19 (FAC, 2011; IFRC 2019) and has been identified as a major challenge in the study areas as reported by North-Horr (20\%), Kalacha (40\%), Turbi (40\%), Marsabit (20\%), Korr (20\%) and Merille (20\%) traders. In addition, traders reported that due to low off-take and limited profits during droughts, they would resort to using seed money for domestic purposes. Owing to frequent drought, traders could not make good savings and thus livestock trade is 'boom and burst' business i.e., they are in good business during normal seasons and consume the money during drought season. Drought also results in seasonality of the markets in the sense that the livestock move to inaccessible areas and those accessible would be in poor body condition for sale. This vicious circle explains why there is low purchasing power among livestock traders.

iii. Fluctuating market prices is a major challenge in the study areas as reported in North-Horr (20\%), Kalacha $(10 \%)$, Turbi (10\%), Marsabit (20\%), Korr (10\%) and Merille (10\%). There is very little information about livestock prices in the study markets and only few respondents would go to market to observe transactions and collect price information firsthand. Most rely on information networks to generate and distribute reliable, timely information about market conditions. A study by Barret et al, 2004 revealed that producers gathered information about livestock prices primarily through traders, but also sort information from friends, relatives, and livestock brokers. However, with the extension of the country's mobile phone service system to the Northern rangelands, it is expected that availability and use of mobile phones is making it easy to communicate about current market conditions in Nairobi and other terminal markets. Besides that, the mobile money saving and sending technology (M-Pesa services) is enhancing livestock trade and reduces risk of cash transactions.

iv. Livestock diseases and quarantines

Traders in Merille (10\%) and Korr (10\%) reported diseases and quarantine as challenges to especially sheep and goat marketing where they cited quarantines as significant sources of price risk by reducing anticipated livestock 
prices received by pastoralists and causing substantial revenue losses to them. The major diseases reported include Rift Valley fever, Rinderpest, trypanosomosis, helminthiasis, Brucellosis and camel fever (ReSSAKS, 2008).

v. Insecurity was identified by traders in North-Horr (10\%), Turbi $(10 \%)$ and Merille $(10 \%)$ as a major challenge to livestock market development. Livestock raiding arising from either other tribes or clans affects trade in the study area. In addition, the influx of automatic weapons has transformed the scope of the danger associated with raids (Fleisher, 2000). It has been debated that insecurity increases the likelihood of market participation in two ways; first an instance of insecurity may compel the pastoralists to relocate to more populous areas thereby increasing the likelihood of market participation. On the other hand insecurity may force pastoralists into the market to purchase animals to replace those lost stock (Barret et al, 2004).

vi. Shortage of water was observed as a challenge by Turbi $(20 \%)$ and Marsabit central (20\%) traders. The study revealed that people and livestock in the study areas entirely rely on surface or ground water. This is true of the rest of the county as there are no permanent rivers but instead springs like Badassa, Songa, Balesa and Bongole which are at 1200-1500 m asl exist. The rest of the springs lie between 400-460 m where the ground water table varies greatly. Marsabit Urban Water Supply which is the only public piped water supply system that serves Marsabit town and its environs has an inconsistent discharge which reduces by over $80 \%$ during drought hence failing to serve its mandate (Marsabit County Government, 2016).

\section{Conclusion}

Livestock marketing has a very high impact on pastoralists' wellbeing. Since pastoralists hold most of their wealth in the form of livestock, markets for animals exert considerable influence over their livelihoods, both by establishing the value of their assets and by affecting herd management decisions.

Similarly, since most traders have no alternative occupation, capital to continue or restart the business after prolonged drought proves to be a big problem that contributes to low capital among the traders. The major challenges experienced in study markets include high capital requirement in starting the business, cash transactions and limited bank services, lack of loaning facilities, poor and fluctuating market prices, high cost of transporting livestock to secondary and terminal markets, drought and water scarcity, livestock diseases and insecurity. High illiteracy and low education levels of traders have led to limited ability to manage records, conduct cost-benefits analysis and understand market forces among other inefficiencies as witnessed when traders for instance, failed to mention market information as an impediment to livestock marketing.

\section{Recommendations}

To address bottlenecks in the livestock marketing in northern Kenya; this study recommends the capacity building of livestock traders on business skills and investments as well as linking livestock traders with banking and loaning institutions. As conventional banks have been known to disregard livestock as equitable assets, there is need to develop a banking system tailor-made for pastoral areas with provision for livestock traders requiring large amounts of loans. M-pesa services can work best to avoid cash theft in those markets.

The study also recommends the coming up with innovative ways of mitigating droughts related risks such as (i) livestock insurance against droughts (ii) promoting pasture/fodder production for finishing livestock before marketing and (iii) orienting pastoralists toward commercializing pastoralism through continuous education. The role of the youth is pivotal in steering the future of livestock production and trade in the ASALs, hence the study proposes their induction in livestock trade.

The study further recommends that both the national and County Government of Marsabit should formulate conducive policies to catalyse livestock off-take from pastoral areas (subsidy) as well as putting in place development agents and pilot loaning institutions that offer low interest loans (revolving fund) for livestock trade in pastoral markets. In addition, the government should support and formalize cross-border trades and link pastoralists with international markets i.e., development modern abattoirs and transport infrastructure in pastoral areas that will export meat.

In order to improve livestock productivity, the study proposes the allocation of sufficient resources for developing adequate water infrastructure and livestock marketing structures, promoting creation of disease free zones, improving extension and advisory support services and developing of strategic feed reserves.

To improve profitability of livestock trade sector, the study recommends public-private participation and investments in livestock processing and value addition hubs in the pastoral areas, development of livestock finishing strategies, development of irrigation infrastructure and surface water harvesting and developing feed banks. Improved road infrastructure and ICT-based information management systems will greatly improve access to livestock inputs and marketing information.

\section{References}

Barnett, V. (1991) Sample Survey: Principles and Methods. St. Edmund Bury Press Ltd., Suffolk and J.W. Arrow Smith Ltd., United Kingdom, pp. 34-36. 
Barret, C.B. (2001) Climate forecasting for pastoralists? Global Livestock Collaborative Research Support Program, Research brief-01-03-PARIMA, December 2001.

Barret, C.B. et al, (2003) Livestock pricing in the Northern Kenyan Rangelands. Journal of African Economics, $12(2): 127-155$

Barret, C.B. et al, (2004) Pastoralist livestock marketing behavior in Northern Kenya and Southern Ethiopia: an analysis of constraints limiting off-take rates. SSRN electronic Journal, posted 1 November 2004.

FAC (Future Agricultures Consortium) 2011. Seeking alternative livelihoods in Northern Kenya: Costs and benefits in health and nutrition. Presented at the International Conference on the Future of Pastoralism on 2123 March 2011

Fleisher, M.L. (2000) Kuria cattle raiders: violence and vigilantism on the Tanzania/Kenya frontier. Ann Arbor: University of Michigan Press.

GoK/UNDP (Government of Kenya/ United Nations Development Fund) 2013. National Human Development Report. 2013. Nairobi: Government Printer.

GoK (Government of Kenya) 1997. Marsabit District Development Plan) 1997-2001. Republic of Kenya, Office of the Vice President and Ministry of Planning and National Development.

GoK (Government of Kenya) 2005. Arid and Semi Arid Lands (ASAL) National Vision and Strategy, Natural Resource Management, 2005-2015.

IFRC (International Federation of the Red Cross and Red Crescent Societies) 2019. Emergency Plan of Action Final Report, Kenya: Drought Appeal

Kibue, M. (2008) Learning to set up a fair trade livestock marketing chain from Maasai pastoralists to consumers in Nairobi, Kenya. The New Agriculturalist, January 2008 edition.

Marsabit County Government, 2016. Environmental impact assessment report for Bakuli 4 dam project and introduction of sewerage system in Marsabit town, Marsabit central Sub-county, Marsabit County.

Marsabit County Government, 2018. Second County Integrated Development Plan 2018-2022.

Mcpeak J. and Barret C.B. (2001) Differential risk exposure and stochastic poverty traps among East African pastoralists. American Journal of Agricultural Economics, 83(3):674-679.

Moser C.A. and Kalton G. (1985) Survey Methods in Social Investigation. Gower Publication, England, pp. 4152.

ReSAKSS, 2008. Investment Opportunities for Livestock in the North Eastern Province of Kenya: A Synthesis of Existing Knowledge. Regional Strategic Analysis and Knowledge Support System (ReSAKSS) East and Central Africa. Working Paper No. 12. 